\title{
EXTENDED SELF: «TЕХНИКА СЕБЯ» В СОВРЕМЕННОМ МИРЕ
}

\author{
Конюхова Татьяна Васильевна', \\ konykhova@tpu.ru \\ Конюхова Екатерина Тимофеевна², \\ konjuhova50@mail.ru \\ Лукьянова Наталия Александровна 1,3 \\ lukianova@tpu.ru \\ Су-Тинг Чен 4 , \\ stchen@mx.nthu.edu.tw \\ Кай-Юань Чэн ${ }^{5}$, \\ kcheng@ym.edu.tw

\section{Родионова Елена Викторовна1,} \\ eva@tpu.ru
}

\author{
${ }^{1}$ Национальный исследовательский Томский политехнический университет, \\ Россия, 634050, Томск, пр. Ленина, 30 \\ 2Новокузнецкий институт (филиал) Кемеровский государственный университет, \\ Россия, 654027, г. Новокузнецк, ул. Циолковского, 23 \\ 3Новгородский государственный университет им. Ярослава Мудрого, \\ Россия, 173003, г. Великий Новгород, ул. Большая Санкт-Петербургская, 41 \\ ${ }^{4}$ Национальный университет Цин Хуа, \\ Тайвань, 300044, Синьчжу, ул. Куанг-Фу, участок 2, № 101 \\ 5 Национальный университет Ян-Мин, \\ Тайвань, 11221, Тайбэй, ул. Линонг, 155
}

Конюхова Татьяна Васильевна, кандидат философских наук, доцент отделения социальногуманитарных наук Школы базовой инженерной подготовки Национального исследовательского Томского политехнического университета.

Конюхова Екатерина Тимофеевна, кандидат педагогических наук, доцент кафедры психологии и общей педагогики Новокузнецкого института (филиала) Кемеровского государственного университета.

Лукьянова Наталия Александровна, доктор философских наук, профессор отделения социальногуманитарных наук Школы базовой инженерной подготовки Национального исследовательского Томского политехнического университета; доктор философских наук, профессор кафедры философии, культурологии и социологии Новгородского государственного университета им. Ярослава Мудрого.

Су-Тинг Чен, доктор философии, профессор, директор Института философии, заведующий междисциплинарной программой гуманитарных и социальных наук Колледжа гуманитарных и социальных наук Национального университета Цин Хуа.

Кай-Юань Чэн, профессор Института философии разума и познания школы гуманитарных и социальных наук Национального университета Ян-Мин.

Родионова Елена Викторовна, кандидат философских наук, доцент отделения социальногуманитарных наук Школы базовой инженерной подготовки Национального исследовательского Томского политехнического университета. 
В статье раскрывается сущность концепта расширенного понимания себя, появившегося в результате слияния онлайн- и офлайн-реальности в единый вещно-предметный континуум. Человек позиционирует себя, свой внутренний мир, демонстрирует самовыражение через соотнесение субъектно-объектной компоненты с собой, свои привязанности и в целом потребление, чтобы поддерживать и продвигать свое чувство идентичности через расширенное «Я» (extended self). Утверждается, что расширенное «Я», определяющее самоидентификацию, самосознание и реализуемое через практику самости и «технику себя» (М. Фуко), позволяет адаптироваться в «жидком мире». Цель работы - показать, что адаптация в мире «я-для-себя» и «я-для-других» возможна через формирование и принятие человеком своего расширенного «Я». Методы исследования: синтез и теоретическое обобщение. Сделан вывод о том, что «техника себя», позволяет найти свое место в современном мире, структурировать представление о себе, обрести себя в реально-виртуальном мире через осознание своего расширенное «Я» в вещно-предметном выражении. Расширенное «Я» влияет на адаптацию и адаптивность личности через преобразование себя для достижения субъективного состояния совершенства, комфорта, признания и пр. Тем самым оно влияет на идентификацию личности в контексте «я-для-себя» и «я-для-других», формирует мифы о должном и недолжном, правилах приспособления к среде и взаимодействия с ней с учетом внутренних и внешних изменений личностного «Я».

Ключевые слова: Расширенное «Я», идентификация, адаптация, «жидкий мир», «техника себя».

\section{Введение}

Цифровые медиа и онлайн-коммуникации трансформировали принципы взаимодействия людей и степень их вовлеченности в мир, процессы потребления, репрезентации и выражения себя. Кроме того, цифровое пространство предоставило нам возможности по-новому покупать, общаться, смотреть и т. д. Что-то мы делаем бессознательно, а что-то вполне осознанно. Мы создаем собственные бренды или онлайн-образы, продвигаем себя с бизнес-аккаунтах и на профессионально ориентированных интернетплощадках с определенной целью, т. е. осознанно. Личные аккаунты мы зачастую наполняем визуальным и содержательным контентом, который близок нам, и делаем это неосознанно. Наш цифровой след в виртуальном пространстве может быть разным, но он отражает нас, наше самосознание, то, как мы себя идентифицируем. В этом ключе человек предстает некоей дискурсивной цифровой личностью, которая имеет коммуникативное равенство с другими, «возможности в конституировании и репрезентации своей субъектности», «реализует самоидентификацию в «ментальности» свободы самовыражения» [1] и расширенное понимание себя и своего «Я».

В условиях радикальных изменений в области технологий, появлении направления цифрового маркетинга и маркетинга социальных сетей, влияющих на потребительское поведение и позиционирование индивидом себя в онлайн- и офлайн-повседневности, трансформация психологических аспектов личности нашла выражение в углубленном изучении вопросов самоидентификации и репрезентативной области субъекта, а также предопределила повышение интереса к теории расширенного «Я» (extended self theory). Термин был предложен в 1988 г. Р. Белком, а сама теория сформировалась на стыке маркетинга, нейробиологии, психологии, философии и ряда прикладных наук.

\section{Расширенное «Я» как новая «техника себя»}

Занимаясь вопросами изучения поведения потребителей, Р. Белк пришел к выводу, что потребляя человек не просто демонстрирует свой статус и возможности, но выражает себя через различные объекты, которые он использует в повседневности, или субъекты, с которыми он взаимодействует, потому что склонен рассматривать все, чем обладает (в материальном или нематериальном смысле), как часть себя и включать его 
в феноменологическое расширенное «Я» [2]. Эта работа определила дальнейший интерес исследователей к изучению феномена потребления как рефлектора самоидентификации человека.

Человек позиционирует себя, свой внутренний мир, демонстрирует самовыражение через соотнесение субъектно-объектной компоненты с собой, свои привязанности и в целом потребление, чтобы поддерживать и продвигать свое чувство идентичности через расширенное «Я» (extended self) $[3,4]$. Эту же идею отчасти продолжает М. Сoломон, полагающий, что расширенное «Я» относится к «определению себя, созданного внешними объектами, которыми человек себя окружает» [5, с. 620].

С развитием ИТ технические и технологические инновации, пространство социальных медиа стали все больше определять нашу личную и социальную жизнь, что породило необходимость учитывать символическое значение внедрения и потребления новых технологий, определяющих личную и социальную идентификацию, влияющую на наше расширенное «Я» $[6,7]$.

В контексте концепции расширенного «Я» самоидентификация включает в себя различные аспекты личности, в т. ч. основные ценности, личностные черты, обязательства и цели, которые есть у человека и которые отражаются в его убеждениях, а также предрасположенности, эмоции, личные качества и отношения с другими людьми [8]. Поэтому наше расширенное «Я» формируется на основании обладания или контроля над некими объектами, создании таких объектов и/или обладании знанием об объекте. Однако в силу изменений окружающего мира трансформируются границы и понимание собственного Я. Человек проецирует и позиционирует себя одновременно в онлайн- и офлайн-пространстве. Ему зачастую сложно переключиться между личинами-образами в этих двух одновременно различных и тесно связанных стихиях. Это определяет текучесть границ себя в современном социально-личностно-технологическом аспекте и трансформацию расширенного «Я».

Одни исследователи изучают феномен расширенного «Я» как самостоятельную единицу без привязки к ментальной сфере [2, 9, 10]. Другие выстраивают доказательную базу взаимозависимости самости и ментальности [11-14]. Тем не менее оба подхода сходятся во мнении, что «Я» - это «реляционная, расширенная и распределенная сущность» $[15]$.

Идея того, что то, чем мы обладаем, является частью нас и выражает/отражает нас, не нова. Еще в 1890 г. У. Джемс в труде «Принципы психологии» заложил основы самости. Он говорил о том, что «Я» человека - это сумма всего, что он может назвать своим, включая свое физическое состояние, одежду, имущество, семью, работу, репутацию и т. д. Все это дает человеку некие эмоции [2, с. 139].

Дискурсивная личность реально-виртуального мира выходит за рамки своего ума и тела. Она создает себя, используя теорию «техники себя» (М. Фуко). Суть этого подхода в том, что человек стремится познать себя, свое тело, душу, действия и поступки, свои мысли, даже зачастую скрываемые от самого себя, «с целью трансформации себя, преобразования себя и достижения состояния совершенства, счастья, чистоты, сверхъестественной силы и т. д.» [16, с. 97; 17]. Осознанно воздействуя на себя, реализуя «практику самости» $[18$, с. 242$]$ для перехода к определенному способу существования, человек расширяет свое «Я», и это позволяет ему адаптироваться в повседневности современности. Поэтому расширенное «Я» можно трактовать как некую новую «технику себя», позволяющую найти свое место в современном мире, структурировать представление о себе, обрести себя в реально-виртуальном мире. Эта техника не изобретается в полном смысле слова самим индивидом, но использует «схемы, которые он находит в 
своей культуре и которые предлагаются, внушаются и навязываются ему его культурой, его обществом и его социальной группой» $[18$, с. 256]. В совокупности все это является ключом для адаптации и понимания вещно-предметной реальности в т. н. «liquid world» («жидкий мир»), основной характеристикой которого выступает трансформирующееся восприятие реальности, где все относительно.

\section{Расширенное «Я» и адаптация в вещно-предметной реальности мира}

Во все времена человеку требуется некий «якорь», стабильность, уверенность для адаптации в социуме. Они необходимы и выступают опорой, упорядочивающий мир в человеке и вокруг него, позволяют делать оценки и выводы, определяют ценности и выступают неким руководством к действию и триггерных ситуациях. Если в прошлом мифы выступали для человека подобным «якорем», систематизирующим реальность, то сегодня это делает офлайн- и онлайн-реальность, подобная двуликому Янусу. Мифы прошлого позволяли прояснить механизмы непонятных природных или социальных явлений через символические формы. В текучем мире современный «миф становится средством поиска своей линии поведения в условиях, когда механизмы социальной действительности в принципе известны, но за плотной сетью коммуникаций или в силу других факторов скрыты от человека» [19, с. 118-119]. Иными словами, поиск себя, своей личной идентичности, характеризующейся одновременным постоянством, изменчивостью и «текучестью» в «жидком мире», не может обойтись без формирования расширенного «Я», определяющего адекватную адаптацию в этом мире. Это напрямую определяется тем, что «я-для-себя» и «я-для-других» могут быть одновременно как различными, так и идентичными. Как указывает Е.О. Труфанова, «идентичность требует согласованности различных аспектов моей личности, как проявляющейся «офлайн», так и «онлайн», но такой согласованности крайне трудно достигнуть» [20, с. 65].

Адаптация, с позиции психологии, выступает ключевым механизмом социализации личности, учитывающим индивидуально-личностные качества индивида. Поэтому она непрерывна, отражает внешнее и внутреннее окружение человека, его приспособление к среде и взаимодействие с ней с учетом внутренних и внешних изменений [21-25]. Кроме того, адаптация отражает включенность личности в системы связей и отношений, наполненных различными ролевыми функциями как в социальном, так и в профессионально-деятельностном плане.

Ж. Пиаже [23, с. 160] описал дуальность адаптации как процесса, в котором имеет место единство изменения окружающего мира личностью и изменения ее внутреннего мира. Иными словами, в адаптации присутствует единство ассимиляции и аккомодации, потому что ассимиляции нет без предварительной или текущей аккомодации, как нет и аккомодации без ассимиляции [26]. Данный аспект тесным образом связан с идентификацией личности в контексте «я-для-себя» и «я-для-других», потому что он предполагает, что формируемое расширенное «Я» определяет самоидентификацию в вещно-предметом континууме офлайн- и онлайн-реальности.

Адаптация психологическая как навык приспособления позволяет человеку самому творить или находить в окружающем мире, в т. ч. виртуальном, «мифы» для поддержания чувства своей идентичности с миром, группой и самим собой через расширенное «Я», находить свое место в этом безграничном пространстве образов, идей, вещей, ощущать сопричастность обществу и самоутверждаться одновременно. Используя формальную форму адаптации, личность реализует «познавательно-информационное приспособление к новому окружению, новым требованиям и обязанностям» [27], которые необходимо реализовывать одновременно в реально-виртуальной действительности. 
В контексте расширенного «Я» маркерами успешной адаптации сегодня выступают различные вещно-предметные проявления: телефон, аватар, одежда, люди и пр. Если наше расширенное «Я» включает те или иные материальные объекты, отражая тем самым наш желаемый образ и позволяющий идентифицировать себя с соответствующей значимой для себя общностью, то мы чувствуем себя комфортно в конкретном реальном и/или виртуальном пространстве. Предположим, что мое расширенное «Я» включает обладание определенной моделью телефона, с помощью которого я могу быть в постоянном контакте со своей онлайн-сущностью и значимым для меня контентом и людьми-образами виртуальной реальности. Одновременно это позволяет мне избегать номофобии и синдрома FOMO. Кроме того, этот же телефон обеспечивает признание меня в реальной действительности как человека, достойного уважения, обладающего определенным уровнем достатка и т. д. Получается, что отчасти я идентифицирую себя со своим телефоном, который становится неотъемлемой частью меня, доставляет мне удовольствие, представляет меня миру и даже выступает продолжением моей руки, фиксирующей мысли, чувства, эмоции, значимую информацию через заметки, фотографии, набор телефонных номеров, поисковые строки и пр. Тем самым я выражаю «я-для-себя». Однако через это же коммуникационное устройство я демонстрирую свое «я-для-других».

\section{Заключение}

Резюмируя сказанное, следует отметить, что современный мир усложняется не только ввиду технологического прогресса, но и ввиду того, что усложняется наше собственное понимание себя. Оно расширяется и включает проявления вещно-предметной действительности реально-виртуального мира. Расширенное «Я» влияет на адаптацию и адаптивность личности через преобразование себя для достижения субъективного состояния совершенства, комфорта, признания и пр. Тем самым оно влияет на идентификацию личности в контексте «я-для-себя» и «я-для-других», формирует мифы о должном и недолжном, правилах приспособления к среде и взаимодействия с ней с учетом внутренних и внешних изменений личностного «Я».

\section{СПИСОК ЛИТЕРАТУРЫ}

1. Попова Д.А. Идентичность как базовый конструкт цифровой личности в межперсональном интернетдискурсе // Вестник Бурятского государственного университета. Язык. Литература. Культура. 2018. - Вып. 2. - С. 63-69.

2. Belk R. Possessions and the extended self // Journal of Consumer Research. - 1988. - V. 15. - P. 139-168.

3. Berger J., Heath C. Where consumers diverge from others: Identity-signaling and product domains // Journal of Consumer Research. - 2007. - V. 34 (2). - P. 121-134. DOI: 10.1086/519142.

4. Kleine R.E., III, Kleine S.S., Kernan J.B. Mundane consumption and the self: a social identity perspective // Journal of Consumer Psychology. - 1993. - V. 2 (3). - P. 209-235.

5. Solomon M. R. Consumer behaviour: buying, having and being. - Boston, MA: Allyn and Bacon, 1994. $660 \mathrm{p}$.

6. Brown S.A., Venkatesh V. Model of adoption of technology in households: A baseline model test and extension incorporating household lifecycle // MIS Quarterly. - 2005. - V. 29 (3). - P. 399-426. DOI: $10.2307 / 25148690$.

7. Arbore A., Soscia I., Bagozzi R.P. The Role of signaling identity in the adoption of personal technologies // Journal of the Association for Information System. - 2014. - V. 15. - Iss. 2. - P. 86-110. DOI: 10.17705/1jais.00352.

8. Bagozzi R.P., Yi Y. Specification, evaluation, and interpretation of structural equation models // Journal of the Academy of Marketing Science. - 2012. - V. 40. - P. 8-34. DOI: 10.1007/s11747-011-0278-x.

9. Wallace K. A theory of the relational self: the cumulative network model // Humane. Mente - Journal of Philosophical Studies. - 2019. - V. 36. - P. 189-220. 
10. Wallace K. The network self: relation, process, and personal identity. - London: Routledge, 2019. - 244 p.

11. Hongladarom S. The online self: externalism, friendship and games. - Dordrecht: Springer, 2016. - 171 p.

12. Howell R. Extended virtues and the boundaries of persons // Journal of the American Philosophical Association. - 2016. - V. 2. - P. 146-163. DOI: https://doi.org/10.1017/apa.2016.5.

13. Milojevic M. Extended mind, functionalism, and personal identity // Synthese. - 2020. - V. 197 (1). P. 2143-2170. DOI: 10.1007/s11229-018-1797-5.

14. Piredda G., Candiotto L. The affectively extended self: a pragmatist approach // Humane. Mente - Journal of Philosophical Studies. - 2019. - V. 36. - P. 121-145.

15. Heersmink R. Varieties of the extended self // Consciousness and Cognition. - 2020. - V. 85. DOI: 10.1016/j.concog.2020.103001.

16. Фуко М. Технологии себя // Логос. - 2008. - № 2. - С . 96-122.

17. Foucault M. Technologies of the Self // Technologies of the Self: A Seminar with Michel Foucault / Ed. by L.H. Martin, H. Gutman, P.H. Hutton. - Amherst: University of Massachusetts Press, 1988. - P. 16-49.

18. Фуко М. Интеллектуалы и власть: Избранные политические статьи, выступления и интервью. Ч. 3. М.: Праксис, 2006. - 320 с.

19. Лукьянова Н.А., Гончаренко М.В., Зинченко Н.С. Научная фантастика как способ к адаптации к миру // Научно-технические ведомости СПбГПУ. Гуманитарные и общественные науки. - 2019. T. 10. - № 3. - C. 113-123.

20. Труфанова Е.О. Идентичность личности в цифровую эпоху: утрата приватности, границы ответственности // Studia Culturae. - 2020. - Вып. 3 (45). - С. 59-68.

21. Андреева Д.А. О понятии адаптации. Исследования адаптации студентов к условиям учебы в вузе // Человек и общество. - Л.: ЛГУ, 1973. - Вып. 13. - С. 62-69.

22. Андреева Г.М. Социальная психология: учебник для высших учебных заведений. - М.: Аспект Пресс, 2014. - 363 c.

23. Пиаже Ж. Избранные психологические труды / пер. с франц. - М.: Международная педагогическая академия, 1994. - 680 с.

24. Овчинникова Г.Г. Социально-психологическая адаптация как фактор становления Я-концепции подростков: дис. ... канд. психол. наук. - М., 1997. - 136 с.

25. Ларионова С.А. Социально-психологическая адаптация личности: теоретическая модель и диагностика: монография. - Белгород: Оригинал, 2002. - 200 с.

26. Piaget J. Biology and Knowledge. - Chicago: University of Chicago Press, 1971. - 384 p.

27. Хаустова А.И. Социально-психологическая адаптация // Молодой ученый. - 2016. - № 26 (130). C. 614-617.

Поступила 08.03.2021 г. 
UDC 316.613

\title{
EXTENDED SELF: «TECHNOLOGIES OF THE SELF» IN THE MODERN WORLD
}

\author{
Tatiana V. Konyukhova1, \\ konykhova@tpu.ru \\ Ekaterina T. Konyukhova2, \\ konjuhova50@mail.ru \\ Natalia A. Lukianova1,3, \\ lukianova@tpu.ru \\ Szu-Ting Chen ${ }^{4}$, \\ stchen@mx.nthu.edu.tw \\ Kai-Yuan Cheng5, \\ kcheng@ym.edu.tw \\ Elena V. Rodionova ${ }^{1}$, \\ eva@tpu.ru \\ ${ }^{1}$ National Research Tomsk Polytechnic University, \\ 30, Lenin avenue, Tomsk, 634050, Russia \\ 2 Kemerovo State University in Novokyznetsk, \\ 23, Tsiolkovskogo street, Novokuznetsk, 654041, Russia \\ 3 Yaroslav the Wise Novgorod State University, \\ 41, Bolshaya St. Peterburgskaya street, Veliky Novgorod, 173003, Russia \\ ${ }^{4}$ National Tsing Hua University, \\ 101, Section 2, KuangFu Road, Hsinchu City, 300044, Taiwan \\ ${ }^{5}$ National Yang-Ming University, \\ 155, Linong Street, Taipei, 11221, Taiwan
}

Tatyana V. Konyukhova, Cand. Sc., associate professor, National Research Tomsk Polytechnic University. Ekaterina T. Konyukhova, Cand. Sc., associate professor, Kemerovo State University in Novokyznetsk.

Natalia A. Lukianova, Dr. Sc., head of Department for Social Sciences and Humanities, National Research Tomsk Polytechnic University; professor, Yaroslav the Wise Novgorod State University.

Szu-Ting Chen, PhD in Philosophy, professor, director, Institute of Philosophy; chair of the Interdisciplinary Program in Humanities and Social Sciences, College of Humanities and Social Sciences, National Tsing Hua University.

Kai-Yuan Cheng, Dr. Sc., professor, National Yang-Ming University.

Elena V. Rodionova, Cand. Sc., associate professor, National Research Tomsk Polytechnic University.

The paper reveals the essence of the concept of an expanded understanding of oneself. It was appeared as a result of the merger of online and offline reality into a single thing-subject continuum. A person positions himself, his inner world, demonstrates self-expression through the correlation of the subject-object component with himself, his attachments and consumption in general. This lets to maintain and promote his sense of identity through the extended self. It is argued that the extended self, that defines self-identification, selfawareness and is realized through the practice of selfhood and «technologies of the self» (M. Foucault), allows one to adapt in the «liquid world». The purpose of the paper is to show that adaptation in the world of 
"I-for-myself» and "I-for-others» is possible through the formation and acceptance by a person of his extended self. The methods used to achieve this goal are synthesis and theoretical generalization. It is concluded that the "technologies of the self» allows one to find one's place in the modern world, to structure the idea of oneself, to find oneself in the real-virtual world through the realization of one's extended self in materialobject expression. The extended self affects the adaptation and adaptability of the personality through transformation of oneself to achieve the subjective state of perfection, comfort, recognition, etc. Thus, it affects the identification of the personality in the context of "I-for-myself» and "I-for-others», create myths about the right and wrong, the rules of interaction, adaptation to the environment and interaction with it.

Key words: Extended self, identification, adaptation, «liquid world», «technologies of the self».

\section{REFERENCES}

1. Popova D.A. Identichnost kak bazovy konstrukt tsifrovoy lichnosti v mezhpersonalnom internet-diskurse [Identity as a basic construct of digital personality in interpersonal Internet discourse]. Vestnik Buryatskogo gosudarstvennogo universiteta. Yazyk. Literatura. Kultura, 2018, no. 2, pp. 63-69.

2. Belk R. Possessions and the extended self. Journal of Consumer Research, 1988, vol. 15, pp. 139-168.

3. Berger J., Heath C. Where consumers diverge from others: identity-signaling and product domains. Journal of Consumer Research, 2007, vol. 34 (2), pp. 121-134. DOI: 10.1086/519142.

4. Kleine R.E., III, Kleine S.S., Kernan J.B. Mundane consumption and the self: a social identity perspective. Journal of Consumer Psychology, 1993, vol. 2 (3), pp. 209-235.

5. Solomon M. R. Consumer behaviour: buying, having and being. Boston, MA, Allyn and Bacon. 1994. $660 \mathrm{p}$.

6. Brown S.A., Venkatesh V. Model of adoption of technology in households: a baseline model test and extension incorporating household lifecycle. MIS Quarterly, 2005, vol. 29 (3), pp. 399-426. DOI: $10.2307 / 25148690$.

7. Arbore A., Soscia I., Bagozzi R.P. The role of signaling identity in the adoption of personal technologies. Journal of the Association for Information System, 2014, vol. 15, Iss. 2, pp. 86-110. DOI: 10.17705/1jais.00352.

8. Bagozzi R.P., Yi Y. Specification, evaluation, and interpretation of structural equation models. Journal of the Academy of Marketing Science, 2012, vol. 40, pp. 8-34. DOI: 10.1007/s11747-011-0278-x.

9. Wallace K. A theory of the relational self: the cumulative network model. Humane. Mente - Journal of Philosophical Studies, 2019, vol. 36, pp. 189-220.

10. Wallace K. The network self: relation, process, and personal identity. London, Routledge. 2019. 244 p.

11. Hongladarom S. The online self: externalism, friendship and games. Dordrecht, Springer. 2016.171 p.

12. Howell R. Extended virtues and the boundaries of persons. Journal of the American Philosophical Association, 2016, vol. 2, pp. 146-163. DOI: https://doi.org/10.1017/apa.2016.5.

13. Milojevic M. Extended mind, functionalism, and personal identity. Synthese, 2020, vol. 197(1), pp. $2143-2170$. DOI: $10.1007 / \mathrm{s} 11229-018-1797-5$.

14. Piredda G., Candiotto L. The affectively extended self: a pragmatist approach. Humane. Mente - Journal of Philosophical Studies, 2019, vol. 36, pp. 121-145.

15. Heersmink R. Varieties of the extended self. Consciousness and Cognition, 2020, vol. 85. DOI: 10.1016/j.concog.2020.103001.

16. Foucault M. Tehnologii sebya [Technologies of the Self]. Logos, 2008, no. 2, pp. 96-122.

17. Foucault M. Technologies of the Self. Technologies of the Self: a seminar with Michel Foucault. Eds. L.H. Martin, H. Gutman, P.H. Hutton. Amherst, University of Massachusetts Press, 1988. pp. 16-49.

18. Foucault M. Intellektualy $i$ vlast: izbrannye politicheskie stati, vystupleniya i intervyu. Ch. 3 [Intellectuals and power: selected political articles, speeches and interviews. P. 3]. Moscow, Praksis Publ., 2006. 320 p.

19. Lukianova N.A., Goncharenko M.V., Zinchenko N.S. Nauchnaya fantastika kak sposob k adaptatsii k miru [A scientific fantasy as a form of adaptation to the future]. Nauchno-tekhnicheskie vedomosti SPbGPU. Gumanitarnye i obshchestvennye nauki, 2019, vol. 10, no. 3, pp. 113-123.

20. Trufanova E.O. Identichnost lichnosti v tsifrovuyu epokhu: utrata privatnosti, granitsy otvetstvennosti [Personal identity in digital age: the loss of privacy, the limits of responsibility]. Studia Culturae, 2020, vol. 3 (45), pp. 59-68.

21. Andreeva D.A. O ponyatii adaptatsii. Issledovaniya adaptatsii studentov k usloviyam ucheby v vuze [About the concept of adaptation. Studies of students' adaptation to the conditions of study at a university]. Chelovek i obshchestvo, 1973, vol. 13, pp. 62-69. 
22. Andreeva G.M. Sotsialnaya psikhologiya [Social Psychology]. Moscow, Aspekt Press, 2014. 363 p.

23. Piaget J. Izbrannye psikhologicheskie trudy [Selected Psychological Works]. Translated from French. Moscow, Mezhdunarodnaya pedagogicheskaya akademiya Publ., 1994. 680 p.

24. Ovchinnikova G.G. Sotsialno-psikhologicheskaya adaptatsiya kak faktor stanovleniya Ya-kontseptsii podrostkov. Dis. Kand. nauk [Socio-psychological adaptation as a factor in the formation of the self-concept of adolescents. Cand. Diss.]. Moscow, 1997. 136 p.

25. Larionova S.A. Sotsialno-psikhologicheskaya adaptatsiya lichnosti: teoreticheskaya model i diagnostika: monografiya [Socio-psychological adaptation of personality: theoretical model and diagnostics: monograph]. Belgorod, Original Publ., 2002. 200 p.

26. Piaget J. Biology and Knowledge. Chicago: University of Chicago Press, 1971. 384 p.

27. Khaustova A.I. Sotsialno-psikhologicheskaya adaptatsiya [Socio-psychological adaptation]. Molodoy ucheny, 2016, vol. 26 (130), pp. 614-617.

Received: 8 March 2021. 